\title{
Wood-decaying Agaricomycetes (Basidiomycota, Fungi): new records for the state of Santa Catarina, Brazil
}

Alice da Cruz Lima Gerlach ${ }^{1,2}$, Marisa de Campos-Santana ${ }^{1}$, Márcio Gutjahr ${ }^{1}$ and Clarice Loguercio-Leite ${ }^{1}$

Submitted: 17 Outober, 2012. Accepted: 19 December, 2012

\begin{abstract}
In this study, we identified six polyporoid species of Agaricomycetes: Abundisporus roseoalbus, Fuscocerrena portoricensis, Oligoporus caesius, Antrodiella duracina, Inocutis jamaicensis and Inonotus venezuelicus. All of these represent new records for the state of Santa Catarina, located in southern Brazil. For Brazil as a whole, this is the second record of $O$. caesius.
\end{abstract}

Key words: Fungal diversity, polypores, taxonomy

Agaricomycetes, formerly basidiomycetes (Hibbett et al. 2007), comprises nearly 21,000 species, including wood-decaying, parasitic and ectomycorrhizal fungi (Hibbett 2006; Kirk et al. 2008). Wood-decaying (white-rot and brown-rot) fungi are the primary agents of lignocellulose degradation (Morgenstern et al. 2008). White-rot fungi degrade all components of the plant cell wall, including hemicellulose, cellulose and lignin (Kersten \& Dan Cullen 2007), whereas brown-rot fungi remove polysaccharides but do not solubilize lignin, which remains as a brown amorphous residue (Aguiar \& Ferraz 2007). In tropical areas, most basidiomycetes $(96 \%)$ are white-rot fungi (Okino et al. 2000).

Over the past three decades, extensive efforts have been made to gather data related to the polypores associated with wood substrates in the state of Santa Catarina, located in southern Brazil. The most recent fungal checklist for the state (Loguercio-Leite et al. 2009) registered 212 species of basidiomycetes, of which seven were new to science (Loguercio-Leite \& Wright 1991a, 1991b, 1998; Loguercio-Leite et al. 1998, 2001, 2002; Baltazar et al. 2009). The aim of this study was to increase the knowledge of Agaricomycetes diversity in Santa Catarina.

The forest vegetation of the state of Santa Catarina is mainly Atlantic Forest with different formations (Fernandes \& Bezerra 1990): mangroves, coastal rain forests, semideciduous forests and Araucaria forests. This study was performed in the municipalities of Aurora

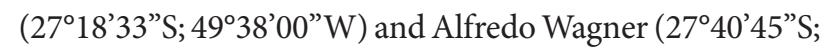
$\left.49^{\circ} 10^{\prime} 38.4^{\prime \prime} \mathrm{W}\right)$. Both sites are located in the Upper Itajaí Valley, in the east-central part of the state. Aurora is covered by dense rain forest and Alfredo Wagner is covered by Araucaria forest.

Periodical fungal samplings were conducted between September 2007 and July 2009. Basidiomata were studied by observing their morphology, including macroscopic characters (e.g., size, color, number of pores/mm, length of tubes) and microscopic characters (presence/absence of structures, size). Measurements were made from slide preparations stained with $1 \%$ aqueous phloxine (plus $1 \%$ and/or $5 \%$ potassium hydroxide) and Melzer's reagent (Ryvarden 1991). We identified specimens down to the species level using specialized bibliographies and comparing with collections of the following herbaria (Thiers 2012): the Herbarium of the Botany Department of the Federal University of Santa Catarina (code, FLOR); the Herbarium of the Biological Sciences Department of the University of Buenos Aires (code, BAFC); and the Herbarium of the Biosciences Institute at the Federal University of Rio Grande do Sul (code, ICN). After having been examined, vouchers were deposited in the FLOR herbarium. Taxonomic arrangement follows Kirk et al. (2008).

We identified six new occurrences of Agaricomycetes in the state of Santa Catarina: Abundisporus roseoalbus (Jungh.) Ryvarden; Oligoporus caesius (Schrad.) Gilb. \& Ryvarden; Fuscocerrena portoricensis (Spreng. ex Fr.) Ryvarden;

\footnotetext{
${ }^{1}$ Universidade Federal de Santa Catarina, Centro de Ciências Biológicas, Departamento de Botânica, Laboratório de Micologia, Florianópolis, SC, Brazil

${ }^{2}$ Author for correspondence: alice_gerlach@yahoo.com.br
} 
Antrodiella duracina (Pat.) I. Lindblad \& Ryvarden; Inocutis jamaicensis (Murrill) A.M. Gottlieb, J.E. Wright \& Moncalvo; and Inonotus venezuelicus Ryvarden. This survey yielded tropical (neotropical and pantropical) or cosmopolitan taxa, mostly white-rot fungi, except for O. caesius which is a brown-rot fungus. For Brazil as a whole, this represents the second record of $O$. caesius.

\section{Polyporaceae Corda}

Abundisporus roseoalbus (Jungh.) Ryvarden, Belg. Jl Bot. 131: 154, 1998.

$\equiv$ Polyporus roseoalbus Jungh., Praem. Fl. Crypt. Javae Insulae:43, 1838.

Description - Parmasto \& Hallenberg (2000).

Distribution - Cosmopolitan. In Brazil, recorded for the states of Bahia, Pará, Paraná and Rio Grande do Sul (Gugliotta et al. 2012).

Comments - In our material, the basidiospore size (4-4.5 $(-5) \times(2-) 2.5-3 \mu \mathrm{m})$ was very similar to the 3.0-4.5 $\times 2.0$ $3.0 \mu \mathrm{m}$ described by Ryvarden \& Johansen (1980). However, Parmasto \& Hallenberg (2000), who considered A. roseoalbus as a synonym of $A$. fuscopurpureus (Pers.) Ryvarden, cited smaller basidiospores $(3.2-3.9(-4.2) \times 2.0-2.8(-3.0) \mu \mathrm{m})$. In addition, we observed a slightly dextrinoid reaction in the basidiospore walls, which is in agreement with the findings of Ryvarden \& Johansen (1980) and Parmasto \& Hallenberg (2000). Another interesting aspect was an ambiguity related to the hyphal system. Ryvarden \& Johansen (op. cit.) stated that $A$. roseoalbus could be considered trimitic (skeletal and binding hyphae) or subtrimitic (skeletal-binding hyphae), as Parmasto \& Hallenberg (op. cit.) assumed. The material examined showed a high number of skeletal-binding hyphae, with a low number of skeletal hyphae.

Voucher material - BRAZIL, Santa Catarina: Aurora, Braço Aurora, Gutjahr \& Strey 238, 23/I/2009, (FLOR 32417). Additional material - BRAZIL, Rio Grande do Sul: Porto Alegre, Morro Santana, M. C. Westphalen 45, 11/ V/2007, (ICN 154098); ibid, M. A. Reck, 14/IV/2005, (ICN 154154 and 154155); ibid: São Francisco de Paula, FLONA, L.V. Graf 91, 02/IX/2006, (ICN 139428).

Fuscocerrena portoricensis (Spreng. ex Fr.) Ryvarden. Transactions of the British Mycological Society 79: 2791982. $\equiv$ Polyporus portoricensis Fr. Elench. Fung. 1: 115. 1828.

Description - Gilbertson \& Ryvarden (1986).

Distribution - Neotropical. In Brazil, recorded for the states of Paraná, Rio Grande do Sul and São Paulo (Gugliotta et al. 2012).

Comments - Easily recognized by the dark brown pileus and whitish-gray hymenophore, with ruptured pores. Diagnostic features include dendrohyphidia limited to hymenium, clamped generative hyphae and cylindrical basidiospores. Dendrohyphidia are always covered with delicate crystals, although it is sometimes difficult to observe this contour, very similar to those described by Gilbertson \& Ryvarden (1986).
Voucher material - BRAZIL, Santa Catarina: Alfredo Wagner, Reserva Rio das Furnas, Gerlach, Reck \& Loguercio-Leite 218, 17/VII/2009, (FLOR 32402).

Additional material - BRAZIL, Rio Grande do Sul: Dom Pedro de Alcântara, M. A. Reck, 04/VII/2008, (ICN 154196).

Oligoporus caesius (Schrad.) Gilb. \& Ryvarden, Mycotaxon 22(2): 365, 1985.

$\equiv$ Boletus caesius Schrad., Spicil. Fl. Germ. 1: 167, 1794.

Description - Ryvarden \& Johansen (1980).

Distribution - Cosmopolitan. In Brazil, recorded for the state of São Paulo [Gugliotta et al. 2012, as Postia caesia (Schrad.) P. Karst.].

Comments - Oligoporus caesius has a very soft, white to bluish basidioma, a monomitic hyphal system, with clamped generative hyphae, amyloid basidiospores and gloeopleurous hyphae. As noted by Loguercio-Leite et al. (2008), gloeopleurous hyphae are always present in this species and absent in two related species, O. subcaesius (A. David) Ryvarden \& Gilb. and O. caesioflavus (Pat.) Baltazar, Michels \& C. L. Leite. The shape and size of the basidiospores (allantoid, 4.0-5.0 × 1.0-1.5 $\mu \mathrm{m}$ ) are similar to the additional material as well to that reported by Rajchenberg (2006). However, Ryvarden \& Johansen (1980) described narrower basidiospores $(4.0-5.0 \times 0.7-1.0 \mu \mathrm{m})$ and Gilbertson \& Ryvarden (1986) mentioned them with larger dimensions (5.5-7.5 $\times 1.0-2.0 \mu \mathrm{m})$. For Brazil as a whole, this is the second record of $O$. caesius.

Voucher material - BRAZIL, Santa Catarina: Aurora, Braço Aurora, Gutjahr \& Strey 97, 23/V/2008 (FLOR 32418). Additional material - ARGENTINA, Buenos Aires: Isla de Martin Garcia, Rajchenberg \& Wright, 9-11/I/1986 (FLOR 11779).

Phanerochaetaceae Jülich

Antrodiella duracina (Pat.) I. Lindblad \& Ryvarden. Mycotaxon 71: 336, 1999.

$\equiv$ Leptoporus duracinus Pat. Bulletin de la Société Mycologique de France 18(2):174, 1902

Description - Lindblad \& Ryvarden (1999).

Distribution - Neotropical. In Brazil, cited for the states of Bahia, Pernambuco, Paraná, Rio Grande do Sul and São Paulo [(Gugliotta et al. 2012, as Tyromyces duracinus (Pat.) Murrill].

Comments - Antrodiella duracina has thin basidioma, concentrically zonate yellow-brownish, pileus, light brown, hymenophore with small pores $(6.0-7.0 \mathrm{~mm})$, with small allantoid basidiospores (3.0-)4.0-6.0 × 1.5-2.0 $\mu \mathrm{m}$, larger than what reported by Lindblad \& Ryvarden data (1999) (4.0-4.5 × 1.0-1.5 $\mu \mathrm{m})$, and skeletal hyphae with large lumen, abundant in the trama and rare in context as detected by Ryvarden \& Guzmán (2001). Despite this, Reck \& Silveira (2008) consider only generative hyphae in context.

Voucher material - BRAZIL, Santa Catarina: Alfredo Wagner, Reserva Rio das Furnas, Gerlach \& Giovanka 54, 
19/IV/2008, (FLOR 32404); ibid, ipse 55, (FLOR 32403); ibid, ipse 131, 07/VII/2008, (FLOR 32405).

Additional material - BRAZIL, Rio Grande do Sul: Porto Alegre, Morro Santana, M. A. Reck, 06/VII/2005 (ICN 154158); ibid, M. C. Westphalen 037, 11/V/2007 (ICN 154091).

Hymenochaetaceae Imazeki \& Toki

Inocutis jamaicensis (Murrill) A. M. Gottlieb, J.E. Wright \& Moncalvo, Mycological Progress 1(3): 308, 2002.

$\equiv$ Inonotus jamaicensis Murrill, Bulletin of the Torrey Botanical Club 31(11): 597, 1904.

Description - Gottlieb et al. (2002).

Distribution - Neotropical. For Brazil cited to Paraná (Gibertoni et al. 2012).

Comments - According to Gottlieb et al. (2002) and Wagner \& Fischer (2002a-b), Inocutis Fiasson \& Niemelä is a monophyletic genus. Inocutis jamaicensis is characterized by a blackish and wrinkled pileus surface with a thin crust, absence of setae (Ryvarden 2005) and reddish brown ellipsoid basidiospores (Rajchenberg 2006). Ryvarden (2005) and Rajchenberg \& Wright (1998) reported longer basidiospores $(6.5-7.3 \times 4.4-5.0 \mu \mathrm{m}$ vs. 5.0-6.0(-7.0) × 3.5-4.5(-5.0) $\mu \mathrm{m}$ in our material). Granular core and sclerified hyphae have not been found, coinciding to Baltazar et al. (2010) who extended this data to all Brazilian specimens examined. Voucher material - BRAZIL, Santa Catarina: Alfredo Wagner, Reserva Rio das Furnas, Gerlach \& Giovanka 84, 07/VII//2008 (FLOR 32327); Gonçalves P. 27, 17/VII/2009 (FLOR 32328).

Additional material - ARGENTINA, Buenos Aires: Alsina, Campo los Pinos, 31/VIII-1978, on dead Eucalyptus viminalis (BAFC 24384).

Inonotus venezuelicus Ryvarden, Mycotaxon 28(2): 529, 1987. = Inonotus serranus Robledo, Urcelay \& Rajchenb. Mycologia 95(2): 348, 2003.

Description - Robledo et al. (2006).

Distribution - Neotropical. In Brazil, recorder for the state of Rio Grande do Norte (Gibertoni et al. 2012).

Comments - Inonotus venezuelicus is very similar to Inocutis jamaicensis. It differs from I. jamaicensis mainly by the absence of a blackish thin crust and by having ellipsoid to ovoid larger basidiospores. In our material, the basidiocarp was effused-reflexed, as reported by Gottlieb et al. (2002) and Robledo et al. (2006), whereas Ryvarden (1987) and Baltazar et al. (2010) described it as typically resupinate. Molecular studies will be necessary to clarify the taxonomy of these species.

Voucher material - BRAZIL, Santa Catarina: Alfredo Wagner, Reserva Rio das Furnas, Gerlach et al. 14, 01/IX/2007 (FLOR 32325); ibid, Gerlach \& Giovanka 76, 07/VII/2008, (FLOR 32324), ibid, ipse 109, 07/VII/2008 (FLOR 32326). Additional material - BRAZIL, Rio Grande do Norte: RPPN Senador Antônio Farias - Mata Estrela, Baía Formosa, Gibertoni, on angiosperms:V/2002 (URM 77459).

\section{Acknowledgments}

We are grateful to the herbarium curators for the loan of their specimens. We also thank Matheus Reck, MSc, as well as Gabriela Giovanka and Renato Rizzaro, for their assistance in the fieldwork.

\section{References}

Aguiar, A. \& Ferraz, A. 2007. Fe3+ and Cu2+ reduction by phenol derivates associated with Azure B degradation in Fenton-like reactions. Chemosphere 66(5): 947-954.

Baltazar, J.M.; Trierveiler-Pereira, L.; Loguercio-Leite, C. \& Ryvarden, L. 2009. Santa Catarina Island mangroves 3: a new species of Fuscoporia. Mycologia 101(6): 859-863.

Baltazar, J.M.; Trierveiler-Pereira, L.; Ryvarden, L. \& Loguercio-Leite, C. 2010. Inonotus s.l. (Hymenochaetales) in the Brazilian herbaria FLOR and SP. Sydowia 62(1): 1-9.

Fernandes, A. \& Bezerra, P. 1990. Estudo fitogeográfico do Brasil. Fortaleza, Stylus Comunicações.

Gibertoni, T.B.; Gomes-Silva, A.C.; Lira, C.R.S.; Melo, G.S.N.; Silva, V.F.; Araújo Neta, L. \& Drechsler-Santos, E.R. 2012. Hymenochaetales. In: Lista de Espécies da Flora do Brasil. Jardim Botânico do Rio de Janeiro. http://floradobrasil.jbrj.gov.br/2012/FB120740. (Accessed July, 2012).

Gilbertson, R.L. \& Ryvarden, L. 1986. North American Polypores, vol.1. Abortiporus - Lindtneria. Oslo, Norway, Fungiflora.

Gottlieb, A.M.; Wright, J.E. \& Moncalvo, J.M. 2002. Inonotus s.l. in Argentina - morphology, cultural characters and molecular analyses. Mycological Progress 1(3): 299-313.

Gugliotta, A.M.; Abrahão, M.C. \& Gibertoni, T.B. 2012. Polyporales. In: Lista de Espécies da Flora do Brasil. Jardim Botânico do Rio de Janeiro. http://floradobrasil.jbrj.gov.br/2012/FB095424. (Accessed July, 2012).

Hibbett, D. 2006. A phylogenetic overview of the Agaricomycotina. Mycologia 98: 917-925.

Hibbett, D.S.; Binder, M.; Bischoff, J.F.; Blackwell, M.; Cannon, P.F.; Eriksson, O.E.; Huhndorf, S.; James, T.; Kirk, P.M.; Lücking, R.; Thorsten L.H; Lutzoni, F.; Brandon, M.P.; McLaughlin, D.J.; Powell, M.J.; Redhead, S.; Schoch, C.L.; Spatafora, J.W.; Stalpers, J.A.; Vilgalys, R.; Aime, M.C.; Aptroot, A.; Bauer, R.; Begerow, D.; Benny, G.L.; Castlebury, L.A.; Crous, P.W.; Dai, Y.C.; Gams, W.; Geiser, D.M.; Griffith, G.W.; Gueidan, C.; Hawksworth, D.L.; Hestmark, G.; Hosaka, K.; Humber, R.A.; Hyde, K.D.; Ironside, J.E.; Kõljalg, U.; Kurtzman, C.P.; Larsson, K-H; Lichtwardt, R.; Longcore, J.; Miadlikowska, J.; Miller, A.; Moncalvo, J.M.; Mozley-Standridge, S.; Oberwinkler, F.; Parmasto, E.; Reeb, V.; Rogers, J.D.; Roux, C.; Ryvarden, L.; Sampaio, J.P.; Schüßler, A.; Sugiyama, J.; Thorn, R.G.; Tibell, L.; Untereiner, W.A.; Walker, C.; Wang, Z.; Weir, A.; Weiss, M.; White, M. M.; Winka, K.; Yao, Y.J. \& Zhang, N. 2007. A higher-level phylogenetic classification of the Fungi. Mycological Research 111: 509-547.

Kersten, P. \& Cullen, D. 2007. Extracellular oxidative systems of the lignin-degrading Basidiomycete Phanerochaete chrysosporium. Fungal Genetics and Biology 44(2): 77-97.

Kirk, P.M.; Cannon, P.F.; David, J.C. \& Stalpers, J. 2008. Ainsworth \& Bisby's dictionary of the fungi. 10. ed. Wallingford, Oxon., CAB international.

Lindblad, I. \& Ryvarden, L. 1999. Studies in Neotropical Polypores 3 - New and interesting Basidiomycetes (Poriales) from Costa Rica. Mycotaxon 71: 335-359.

Loguercio-Leite, C. \& Wright, J.E. 1991a. Contribution to a biogeographical study of the austroamerican xilophilous polypores (Aphyllophorales) from Santa Catarina Island, SC, Brazil. Mycotaxon 41: 161-166.

Loguercio-Leite, C. \& Wright, J.E. 1991b. New South American pileate polypores (Polyporaceae) from Santa Catarina Island, SC, Brazil. Mycotaxon 41: 167-172. 
Loguercio-Leite, C. \& Wright, J. E. 1998. Diplomitoporus dilutabilis a new species of Polyporaceae (Aphyllophorales) from Santa Catarina Island, Brazil. Mycotaxon 68: 47-51.

Loguercio-Leite, C.; Gerber, A.L. \& Ryvarden, L. 1998. Wrigthoporia porilacerata, a new species of pore fungi from southern Brazil. Mycotaxon 67: 251-255.

Loguercio-Leite, C.; Gonçalves, G.V. \& Ryvarden, L. 2001. Studies in Neotropical polypores 13. Ceriporiopsis cystidiata sp. nov. Mycotaxon 79: 285-288.

Loguercio-Leite, C.; Ryvarden, L. \& Groposo, C. 2002. Studies in Neotropical polypores 16. Rubroporus carneoporis genus \& species nova. Mycotaxon 83: 223-227.

Loguercio-Leite, C.; Michels, J. \& Baltazar, J. M. 2008. Austro-American lignolytic polypores (Agaricomycetes) - new records for Southern Brazil. Mycotaxon 104: 205-213.

Loguercio-Leite, C.; Campos-Santana, M.; Gerlach, A.; Gutjahr, M.; Trierveiler-Pereira, L.; Drechsler-Santos, E. R. \& Baltazar, J.M. 2009. Résumé of macromycetes from Santa Catarina State, Southern Brazil. Insula (Florianópolis) 38: 01-14.

Morgenstern, I.; Klopman, S. \& Hibbett, D.S. 2008. Molecular Evolution and Diversity of Lignin Degrading Heme Peroxidases in the Agaricomycetes. Journal Molecular Evolution 66:243-257.

Okino, L.K.; Machado, K.M.G.; Fabris, C. \& Bononi, V.L.R. 2000. Lignolytic activity of tropical rainforest Basidiomycetes. World Journal of Microbiology \& Biotecnology 16: 889-893.

Parmasto, E. \& Hallenberg, N. 2000. The genus Abundisporus (Hymenomycetes, Basidiomycotina). Karstenia 40: 129-138.

Rajchenberg, M. \& Wright, J.E. 1998. Two interesting Polypore species (Hymenochaetales) from Argentina. Folia Cryptogamica Estonica 33: $119-122$.
Rajchenberg, M. 2006. Los Políporos (Basidiomycetes) de los Bosques Andinos Patagónicos de Argentina. Bibliotheca Mycologica 201: 1-300.

Reck, M.A. \& Silveira, R.M.B. 2008. Ordem Polyporales (Basidiomycota) no Parque Estadual de Itapuã, Viamão, Rio Grande do Sul. Revista Brasileira de Biociências (Impresso) 6: 301-314.

Robledo, G.; Urcelay, C.; Domínguez, L. \& Rajchenberg, M. 2006. Taxonomy, ecology and biogeography of polypores (Basidiomycetes) from Argentinian Polylepis woodlands. Canadian Journal of Botany 84: 1561-1572.

Ryvarden, L. 1987. New and noteworthy polypores from tropical America. Mycotaxon 28(2): 525-541.

Ryvarden, L. 1991. Genera of polypores - Nomenclature and taxonomy. Synopsis Fungorum 5: 1-363.

Ryvarden, L. 2005. The genus Inonotus a synopsis. Synopsis Fungorum 21: 1-149.

Ryvarden, L. \& Johansen, I. 1980. A preliminary polypore flora of East Africa. Oslo, Fungiflora.

Ryvarden, L. \& Guzmán, G. 2001. Studies in neotropical polypores 12 New and noteworthy polypores from Mexico. Mycotaxon 78: 245-256.

Thiers, B. (continuously updated). Index Herbariorum. New York, New York Botanical Garden. http://sciweb.nybg.org/science2/IndexHerbariorum.asp. (Accessed July, 2012).

Wagner, T. \& Fischer, M. 2002a. Classification and phylogenetic relationships of Hymenochaete and allied genera of the Hymenochaetales, inferred from rDNA sequence data and nuclear behaviour of vegetative mycelium. Mycological Progress 1: 93-104.

Wagner, T. \& Fischer, M. 2002b. Proceedings towards a natural classification of the worldwide taxa Phellinus s.l. and Inonotus s.l., and phylogenetic relationships of allied genera. Mycologia 94: 998-1016. 
